\title{
Genome-Wide Analysis of Carboxylesterases (COEs) in the Whitefly, Bemisia tabaci (Gennadius)
}

\author{
Jixing Xia ${ }^{1,+} \mathbb{C}$, Haifeng $X u^{1,+}$, Zezhong Yang ${ }^{1,+}$, Huipeng Pan ${ }^{2}$, Xin Yang ${ }^{1}$, Zhaojiang Guo ${ }^{1}{ }^{\circledR}$, \\ Fengshan Yang ${ }^{3}$, Litao Guo ${ }^{1}$, Xiaodong Sun ${ }^{1}$, Shaoli Wang ${ }^{1}$, Qingjun Wu ${ }^{1}$, Wen Xie ${ }^{1}$ \\ and Youjun Zhang $1, * \mathbb{B}$ \\ 1 Department of Plant Protection, Institute of Vegetables and Flowers, Chinese Academy of Agricultural \\ Sciences, Beijing 100081, China; jixingxia@126.com (J.X.); xhf846664635@163.com (H.X.); \\ yangzhezhong_1988@126.com (Z.Y.); xinyang3856@163.com (X.Y.); guozhaojiang@caas.cn (Z.G.); \\ guolitao@caas.cn (L.G.); xiaodong0429@126.com (X.S.); wangshaoli@caas.cn (S.W.); \\ wuqingjun@caas.cn (Q.W.); xiewen@caas.cn (W.X.) \\ 2 Key Laboratory of Bio-Pesticide Innovation and Application of Guangdong Province, South China \\ Agricultural University, Guangzhou 510642,China; panhuipeng@scau.edu.cn \\ 3 Key Laboratory of Molecular Biology of Heilongjiang Province, College of Life Sciences, Heilongjiang \\ University, Harbin 150080, China; yangfshan@126.com \\ * Correspondence: zhangyoujun@caas.cn; Tel.: +86-10-82109518 \\ + These authors contributed equally.
}

Received: 2 September 2019; Accepted: 7 October 2019; Published: 9 October 2019

\begin{abstract}
The whitefly (Bemisia tabaci), an important invasive pest that causes severe damage to crops worldwide, has developed resistance to a variety of insecticides. Carboxylesterases (COEs) are important multifunctional enzymes involved in the growth, development, and xenobiotic metabolism of insects. However, systematic studies on the COEs of B. tabaci are scarce. Here, 42 putative COEs in different functional categories were identified in the Mediterranean species of B. tabaci (B. tabaci MED) based on a genome database and neighbor-joining phylogeny. The expression patterns of the COEs were affected by the development of $B$. tabaci. The expression levels of six COEs were positively correlated with the concentration of imidacloprid to which $B$. tabaci adults were exposed. The mortality of B. tabaci MED adults fed dsBTbe5 (67.5\%) and dsBTjhe2 (58.4\%) was significantly higher than the adults fed dsEGFP (41.1\%) when treated with imidacloprid. Our results provide a basis for functional research on COEs in $B$. tabaci and provide new insight into the imidacloprid resistance of $B$. tabaci.
\end{abstract}

Keywords: carboxylesterases; Bemisia tabaci; expression profile; imidacloprid resistance

\section{Introduction}

Carboxylesterases (COEs) are multi-gene superfamily enzymes with an $\alpha / \beta$-hydrolase fold that can hydrolyze carboxyl esters into corresponding alcohols and acids [1], and are widely found in animals [2] (including insects [3]), plants [4], and microorganisms [5]. COEs have a wide range of biological functions; they are not only involved in the important process of nerve development, but also participate in the degradation of hormones and pheromones [6]. More importantly, as important metabolic enzymes, COEs participate in the detoxification of ester-containing xenobiotics such as drugs, insecticides, and environmental toxicants [7].

In insects, studies on COEs have mainly focused on their roles in insecticide resistance. The mutation of COE coding sequences is related to organophosphorus resistance in Hemiptera (Bemisia tabaci Middle East-Asia Minor 1 (MEAM1) [8] and Aphis gossypii [9]), Lepidoptera (Plodia interpunctella [10]), Hymenoptera (Anisopteromalus calandrae [11]), and Diptera (Lucilia cuprina [12] and 
Musca domestica [13]). The overexpression of COEs caused by gene amplification or transcriptional upregulation is involved in insecticide resistance in Hemiptera (B. tabaci MEAM1 [8], Nilaparvata lugens [14], and A. gossypii [15]), Lepidoptera (Helicoverpa armigera [16]), Hymenoptera (Habrobracon hebetor [10]), and Diptera (Culex quinquefasciatus [17]). The induction of COE gene expression by insecticides is considered an important cause of insecticide resistance in Hemiptera (A. gossypii Glover [18]), Coleoptera (Leptinotarsa decemlineata [19]), Diptera (Aedes aegypti [20]), and Arachnida (Tetranychus cinnabarinus [21]). COEs frequently increase insecticide resistance through gene coding sequence mutations, constitutive overexpression, inductive expression, or a combination of these mechanisms [10].

The whitefly, B. tabaci (Gennadius), is one of the 100 most catastrophic invasive species in the world [22]. This typical phloem sap-feeding insect causes severe crop reductions by directly feeding on phloem, transmitting various plant viruses, and excreting honeydew. Over 600 different plant species, including crops and ornamentals, have been documented as hosts of B. tabaci [23]. B. tabaci is a species complex that includes at least 30 cryptic species [24]. Among these species, the MEAM1 species (formerly biotype B) and Mediterranean species (MED, formerly biotype Q) are considered the most invasive and destructive cryptic species [25]. In most parts of China, the previously dominant $B$. tabaci MEAM1 has been replaced by B. tabaci MED due to the overuse of insecticides [26-28].

Neonicotinoid insecticides are an important class of chemical insecticides that are used worldwide because of their high toxicity to a range of important pests [29-31]. With increased neonicotinoid insecticide use, insects inevitably develop resistance [31]. B. tabaci was the first insect to develop resistance to imidacloprid [32], and B. tabaci resistance to neonicotinoid insecticides (including imidacloprid) has been reported globally [27,33-37]. The detoxification enzymes glutathione S-transferase and cytochrome P450 monooxygenases are involved in the resistance of $B$. tabaci to imidacloprid [34,38-42]. However, whether COEs contribute to B. tabaci MED tolerance of imidacloprid has not been investigated.

Recently, our group sequenced the transcriptome and genome of B. tabaci MED [43,44], providing a solid foundation for a comprehensive study of whitefly COE family genes at the genome level. In the current study, we provide genome-wide annotation and classification of COEs in the B. tabaci MED genome by constructing a phylogenetic tree with homologous genes from Apis mellifera and Drosophila melanogaster. We then characterized the expression patterns of COE genes affected by developmental stage and investigated the expression profiles of the $\mathrm{COE}$ genes in response to imidacloprid challenge. Finally, RNA interference (RNAi) was used to determine which COEs are involved in B. tabaci MED defense against imidacloprid.

\section{Results}

\subsection{Identification of COEs in the Genome of B. tabaci MED}

Through genomic analysis and transcriptome correction, a total of 42 putative COEs were identified in the genome of $B$. tabaci MED (Table S1). These COEs were located on 34 scaffolds, among which scaffolds 673 and 4145 each contained two COEs and scaffolds 39, 436, and 601 each contained three COEs (Table S1). The lengths of COE coding proteins ranged from 302 to 932 amino acids (Table S1). A neighbor-joining (NJ) phylogenetic tree of COEs was constructed with MEGA 6.0 using multiple alignments of amino acid sequences from B. tabaci MED, A. mellifera, and D. melanogaster to survey gene phylogenetic relationships. The phylogenetic tree divided the insect COEs into nine clades that were clustered into three groups: the intracellular catalytic class, secreted catalytic class, and neurodevelopmental class (Figure 1, Table S1). Six COEs belonged to alpha esterase, which was the only clade in the intracellular catalytic class. Seventeen COEs were involved in secreted catalytic processes: fifteen beta esterases, three juvenile hormone esterases (JHEs), one glutactin, and one uncharacterized esterase. The neurodevelopmental class included 16 COEs: ten neuroligins, four acetylcholinesterases, one gliotactin, and one uncharacterized esterase. Acyrthosiphon pisum and B. tabaci contained more 
beta esterase genes but fewer alpha esterase genes than the other five insects. B. tabaci contained the largest number of neuroligin genes (Table 1).

Table 1. The distribution of carboxylesterase (COE) genes in B. tabaci MED and other insects

\begin{tabular}{|c|c|c|c|c|c|c|c|}
\hline Class/Clades & $\begin{array}{c}\text { B. } \\
\text { mori }\end{array}$ & $\begin{array}{c}D . \\
\text { melanogaster }\end{array}$ & $\begin{array}{c}\text { Ap. } \\
\text { mellifera }\end{array}$ & $\begin{array}{c}\text { An. } \\
\text { gambiae }\end{array}$ & $\begin{array}{c}T . \\
\text { castaneum }\end{array}$ & $\begin{array}{c}\text { A. } \\
\text { pisum }\end{array}$ & $\begin{array}{c}B . \\
\text { tabaci }\end{array}$ \\
\hline \multicolumn{8}{|c|}{ Intracellular catalytic class } \\
\hline$\alpha$-esterase & 55 & 13 & 8 & 16 & 26 & 5 & 6 \\
\hline \multicolumn{8}{|c|}{ secreted catalytic class } \\
\hline JHE & 4 & 2 & 1 & 9 & 1 & 0 & 3 \\
\hline $\begin{array}{l}\text { integument } \\
\text { esterase }\end{array}$ & 2 & 3 & 1 & 0 & 2 & 0 & 0 \\
\hline$\beta$-esterase & 2 & 6 & 3 & 5 & 8 & 15 & 15 \\
\hline uncharacterized & 1 & 1 & 1 & 1 & 1 & 1 & 1 \\
\hline glutactin & 0 & 4 & 0 & 9 & 0 & 0 & 1 \\
\hline \multicolumn{8}{|c|}{ neurodevelopmental class } \\
\hline AChE & 2 & 1 & 2 & 2 & 2 & 2 & 4 \\
\hline uncharacterized & 1 & 1 & 1 & 1 & 1 & 1 & 1 \\
\hline gliotactin & 1 & 1 & 1 & 1 & 1 & 1 & 1 \\
\hline neuroligin & 6 & 4 & 5 & 5 & 4 & 3 & 10 \\
\hline neurotactin & 2 & 1 & 1 & 2 & 2 & 0 & 0 \\
\hline total & 76 & 37 & 24 & 51 & 48 & 28 & 42 \\
\hline
\end{tabular}

A. pisum, Acyrthosiphon pisum; An. gambiae, Anopheles gambiae; Ap. mellifera, Apis mellifera; B. mori, Bombyx mori; B. tabaci, Bemisia tabaci MED; D. melanogaster, Drosophila melanogaster; T. castaneum, Tribolium castaneum. AChE: acetylcholinesterase; JHE, juvenile hormone esterase. 

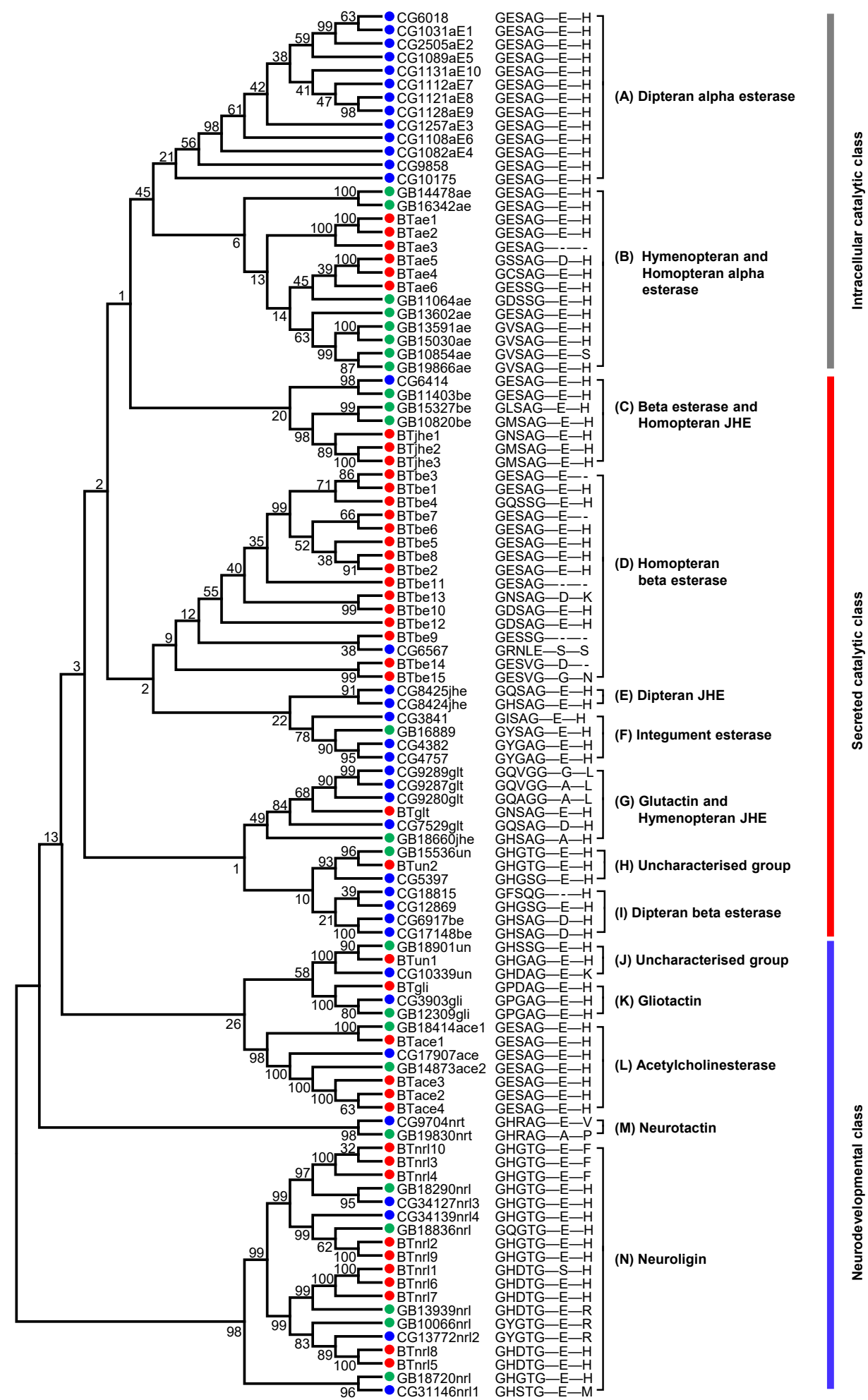

Figure 1. Phylogenetic tree of COEs in B. tabaci MED. A total of $103 \mathrm{COE}$ amino acid sequences were used in the phylogenetic analysis. The phylogenetic tree was constructed using MEGA 6 with the neighbor-joining (NJ) method based on the Jones-Taylor-Thornton (JTT) model with a uniform substitution rate. Bootstrap values shown at branch points are expressed as percentages calculated from 1000 replicates. The catalytic residues and GXSXG consensus sequence around serine active site are shown at the right of the phylogenetic tree. B. tabaci MED (red circles); D. melanogaster (blue circles); A. mellifera (green circles). 


\subsection{Expression Profiling of B. tabaci MED COE Genes}

COE family genes are involved in multiple processes of insect growth and development; thus, their expression levels may vary among developmental stages. To determine the expression profiles of COEs across different developmental stages of B. tabaci MED, we extracted the total RNA from eggs, 1st-2nd-instar nymphs, 3rd-instar nymphs, 4th-instar nymphs, and adults. COE expression levels were examined using RNA-seq. The log2-transformed expression values (FPKM-fragments per kilobase of transcript per million fragments mapped) of COE genes are shown in Figure 2 (Table S3). Hierarchical clustering was carried out using Gene Cluster 3.0 with the centroid linkage method (Figure 2). In the hierarchical clustering results, 3rd- and 4th-instar nymphs first clustered together and then clustered with eggs and 1st-2nd-instar nymphs. Males and females first clustered together and then clustered with other developmental stages.
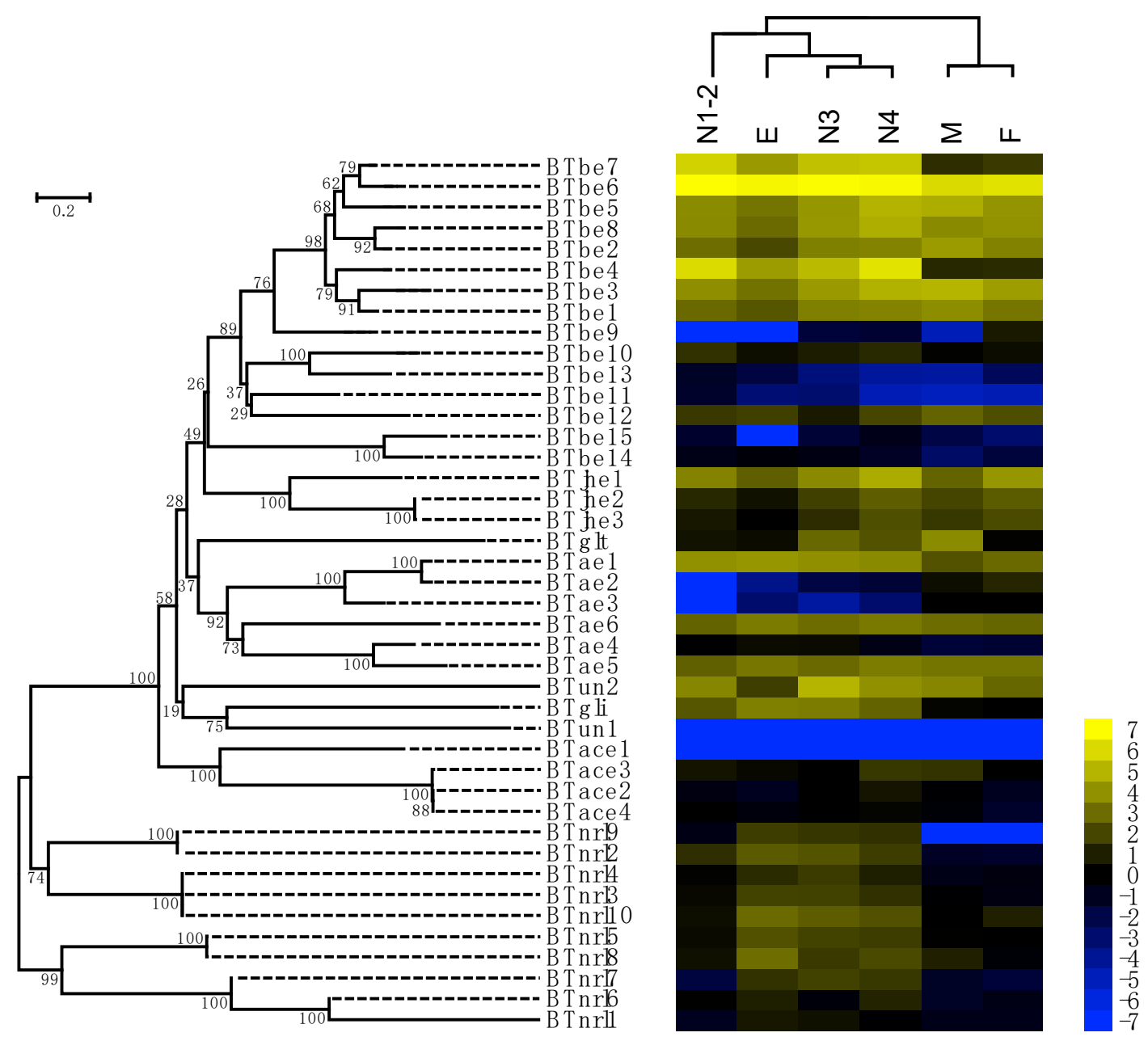

Figure 2. Expression of COE genes among B. tabaci MED developmental stages. The phylogenetic tree on the left shows the phylogenetic relationships of COE in B. tabaci MED. A total of $42 \mathrm{COE}$ amino acid sequences of $B$. tabaci MED were aligned by MUSCLE, and the phylogenetic tree was constructed by MEGA 6.0 using the NJ method based on the JTT model with a uniform substitution rate. Bootstrap values displayed at branch points are expressed as percentages of 1000 replicates. The color scale is displayed on the right side; yellow represents higher expression values (log2-transformed FPKM values), while blue represents lower expression values (log2-transformed FPKM values). E, Egg; N1-2, 1st- and 2nd-instar nymphs; N3, 3rd-instar nymph; N4, 4th-instar nymph; M, Male; F, Female.

BTbe6 was highly expressed at all stages of development, while BTun1 and BTace1 were largely undetectable in transcriptional analysis. Examination of the secreted catalytic class showed that BTbe 7 
expression was significantly lower in adults than at other stages. BTbe4 was downregulated in male and female adults but highly expressed in 1st-2nd-instar nymphs and 4th-instar nymphs. BTbe9 expression was significantly higher in female adults and lower in eggs, males, and 1st-2nd-instar nymphs. The BTbe15 had significantly lower expression in eggs than at other stages. BTjhe genes were most highly expressed in 4th-instar nymphs, followed by female adults. BTun2 exhibited the highest expression in 3rd-instar nymphs and lowest expression in eggs. BTglt was upregulated in male adults. In the intracellular catalytic class, BTae1 was downregulated while BTae 2 and BTae 3 were upregulated in male and female adults. In the neurodevelopmental class, most of the BTnrl genes had the highest expression level in eggs, except for BTnrl3, BTnrl6, and BTnrl7, and all BTnrl genes were expressed at low levels in male and female adults. BTace genes except for BTace1 were more highly expressed in 4th-instar nymphs than at the other stages.

In order to verify the expression profile data obtained from the transcriptome, qRT-PCR was performed to analyze the expression of $12 \mathrm{COEs}$, which covered each of the COE clades, at different stages of $B$. tabaci MED development. The expression levels of 7 of the 12 COEs obtained by qRT-PCR were significantly consistent with the FPKM expression pattern $(p<0.05)$ (Figure 3$)$.

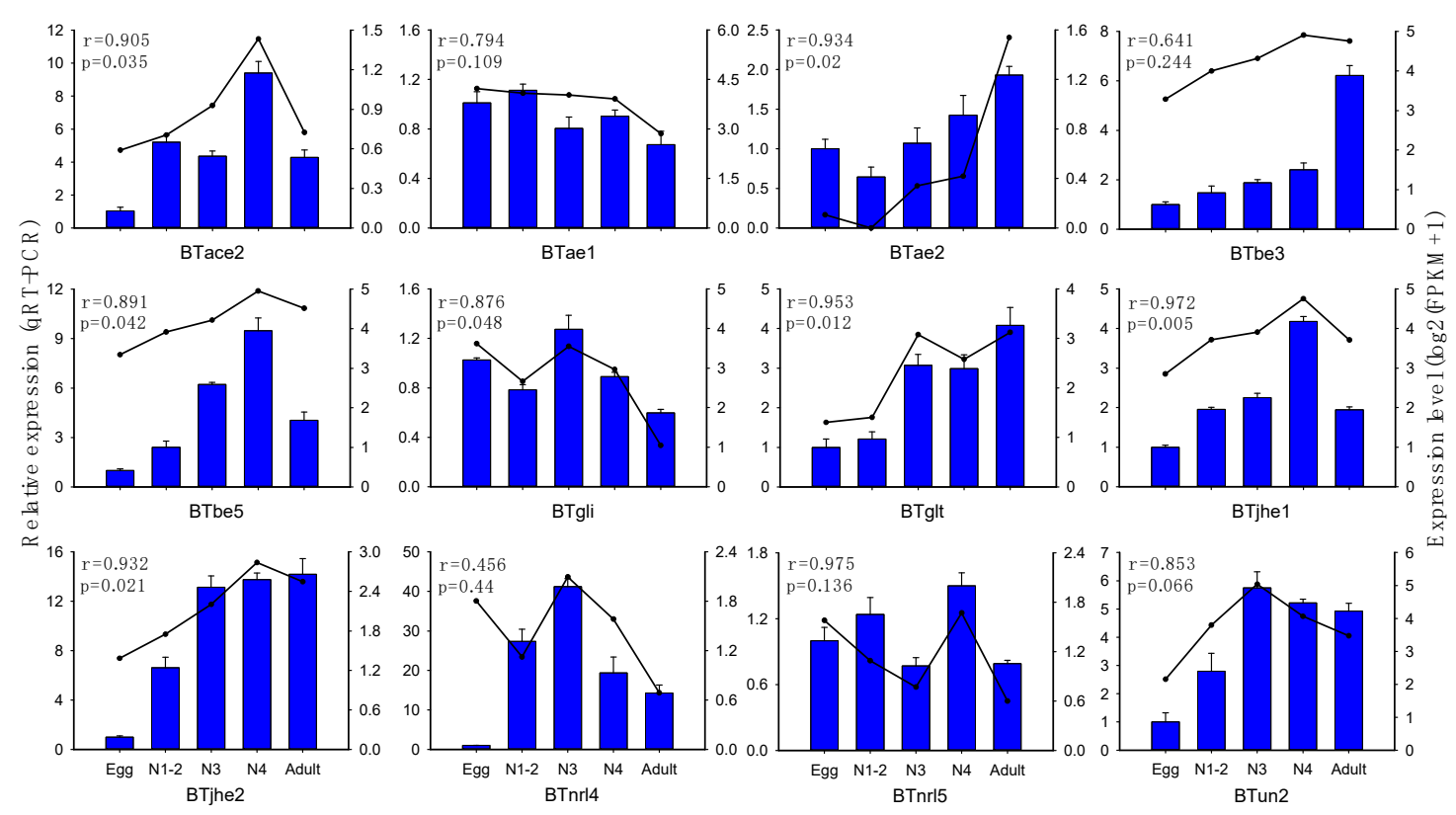

Figure 3. qRT-PCR-based expression profiling of COE genes at different stages of B. tabaci MED development. Total RNA was extracted during individual developmental stages of $B$. tabaci MED and used to analyze the expression levels of COEs with qRT-PCR. FPKM values were used to determine the transcript levels of COEs with RNA-seq, and the results are expressed in the form of $\log 2(\mathrm{FPKM}+1)$. Correlation between RNA-seq and qRT-PCR were tested using SPSS 23 with Pearson and two-tailed test, r, Pearson correlation; $p$, significant. E, Egg; N1-2, 1st- and 2nd-instar nymphs; N3, 3rd-instar nymph; N4, 4th-instar nymph; A, Adult.

\subsection{Responses of COE Expression to Imidacloprid}

To investigate the tolerance of $B$. tabaci to imidacloprid challenge, we analyzed the expression profiles of all COEs in response to imidacloprid using the leaf-dip bioassay method with imidacloprid concentrations of 0 (control), 25, 50, and $100 \mathrm{mg} / \mathrm{L}$ [44]. The expression of most of COE genes (except for eight COE genes of the beta esterase clades (BTbe8, BTbe10, BTbe12, BTbe14, and BTbe15), all four acetylcholinesterases, and BTjhe3, BTae5, BTglt, and BTnrl8) was induced by imidacloprid, and the results are shown in Table S4. The expression levels of BTbe5, BTbe3, BTjhe1, BTjhe2, BTae2, and BTun 2 induced by $100 \mathrm{mg} / \mathrm{L}$ imidacloprid were higher than those induced by $50 \mathrm{mg} / \mathrm{L}$ imidacloprid, followed by $25 \mathrm{mg} / \mathrm{L}$ imidacloprid induction. The expression levels of these genes were lowest in the 
control group with no imidacloprid (Figure 4, Table S4). The COE genes whose expression levels were positively correlated with imidacloprid concentration were used for subsequent study, as these genes are more likely to participate in whitefly resistance to imidacloprid.

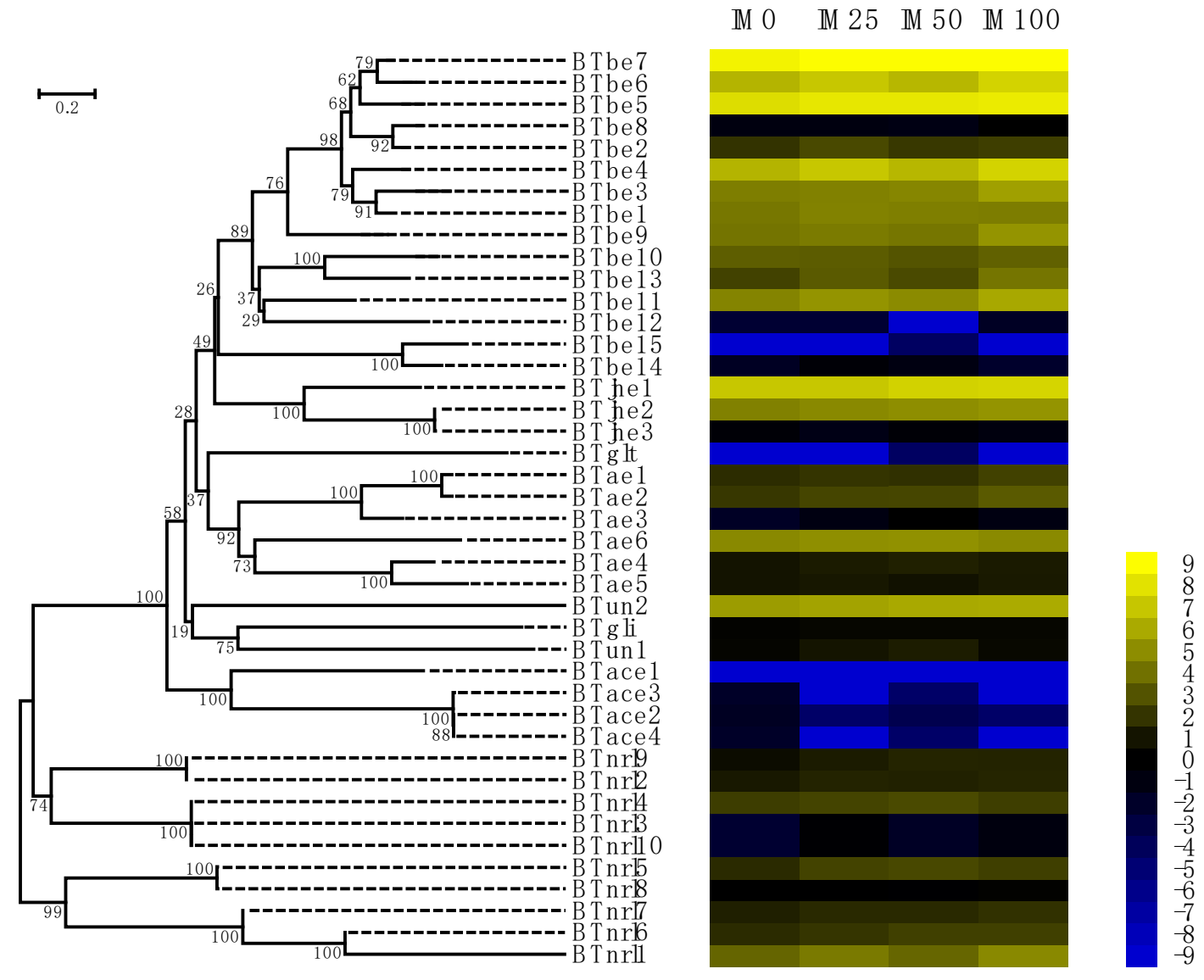

Figure 4. Expression of COE genes in B. tabaci MED adults treated with an imidacloprid gradient. A total of 14 COE amino acid sequences of $B$. tabaci MED were aligned by MUSCLE, and the phylogenetic tree was constructed by MEGA 6.0 using the NJ method based on the JTT model with a uniform substitution rate. Bootstrap values displayed at branch points are expressed as percentages of 1000 replicates. The color scale is displayed on the right side; yellow represents higher expression values (log2-transformed FPKM values), while blue represents lower expression values (log2-transformed FPKM values). IM0, whitefly treated with water; IM25, whitefly treated with $25 \mathrm{mg} / \mathrm{L}$ imidacloprid; IM50, whitefly treated with $50 \mathrm{mg} / \mathrm{L}$ imidacloprid; IM100, whitefly treated with $100 \mathrm{mg} / \mathrm{L}$ imidacloprid.

\subsection{COEs Involved in the Imidacloprid Resistance of B. tabaci MED}

To determine whether the COEs mentioned above are related to the imidacloprid resistance of $B$. tabaci MED, RNAi was performed to knock down the expression of these genes by feeding dsRNA of COEs to B. tabaci adults, and a bioassay was used to assess mortality. The expression levels of COEs in B. tabaci fed COE dsRNA for $48 \mathrm{~h}$ were significantly lower than those in adults fed enhanced green fluorescent protein (EGFP) dsRNA $(p<0.05 ; n=3$; Figure 5$)$. The bioassay results showed that there was no significant difference in the mortality of $B$. tabaci adults fed buffer (without dsRNA) (37.3\%) or dsEGFP (41.1\%) when the adults were treated with imidacloprid at $50 \mathrm{mg} / \mathrm{L}(p<0.05 ; n=3$; Figure 6). The mortality of B. tabaci MED adults fed dsRNA of BTbe5 (67.5\%) and BTjhe2 (58.4\%) was significantly higher than that of adults fed dsRNA of EGFP (41.1\%) when treated with imidacloprid $(p<0.05 ; n=3$; Figure 6). 

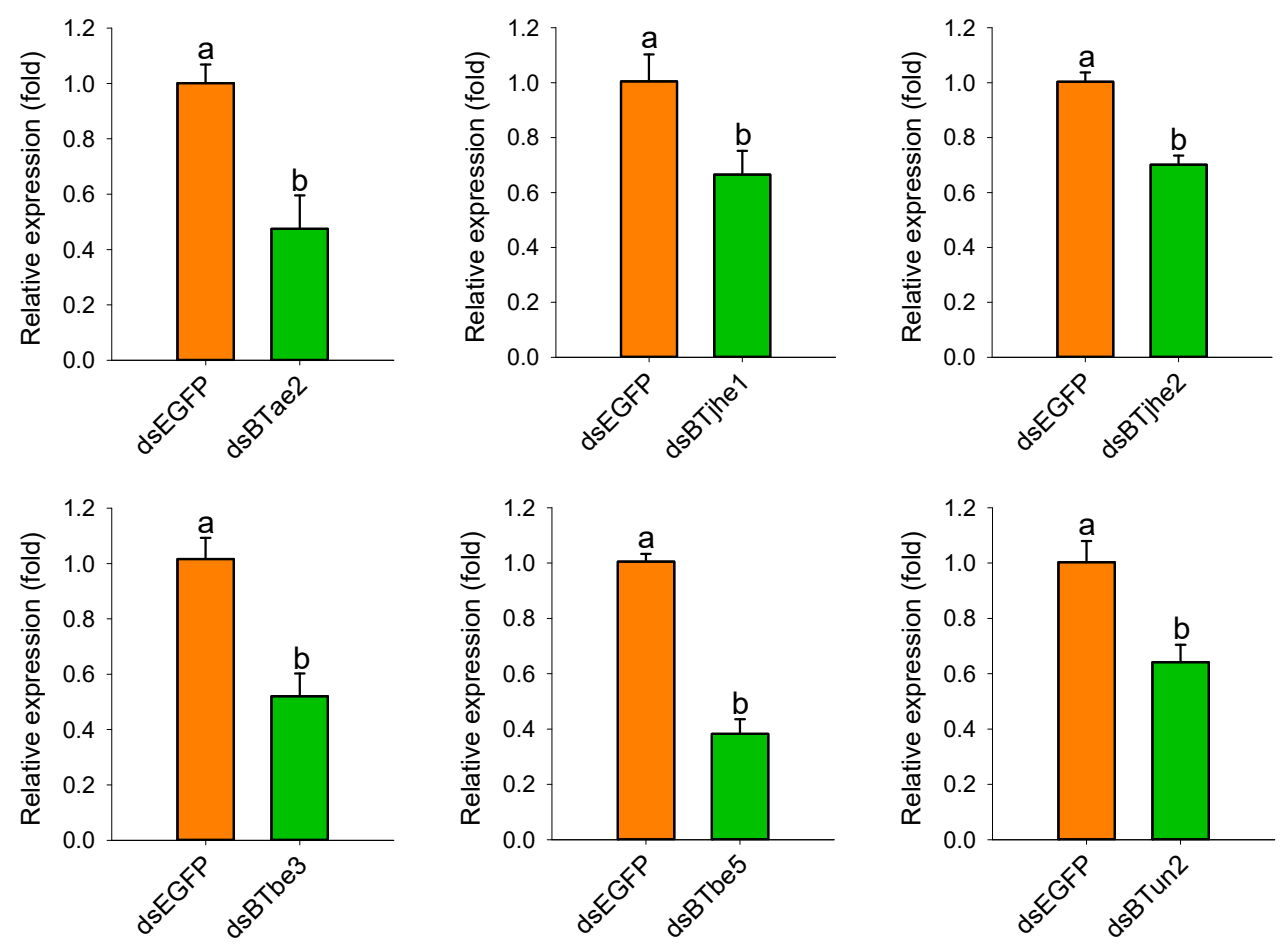

Figure 5. Silencing of COE gene expression by oral feeding of dsRNA. Suppression of COE gene expression after B. tabaci MED adults were fed dsRNA for $48 \mathrm{~h}$, with adults fed dsEGFP as a control. The expression of COE genes was detected by qRT-PCR with EF1- $\alpha$ and RPL29 as internal reference genes. Different letters above the bars indicate significant differences between treatments $(p<0.05$; Holm-Sidak test; $n=3$ ).

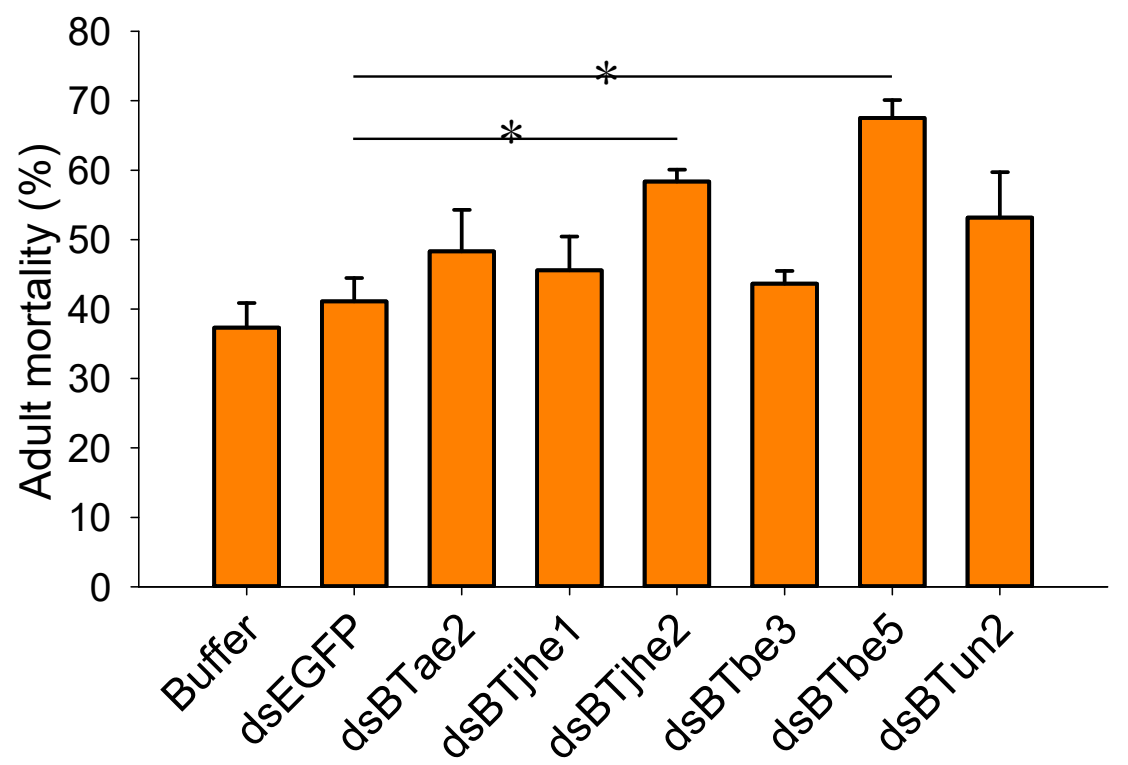

Figure 6. Effect of silencing COE genes on B. tabaci susceptibility to imidacloprid. Susceptibility to imidacloprid in B. tabaci adults fed buffer (without dsRNA), dsEGFP, or dsRNA targeting COE genes was tested using feeding chambers. Asterisks indicate significant differences between treatments (dsRNA) and the control (dsEGFP) ( $p<0.05$; Holm-Sidak test; $n=3)$.

\section{Discussion}

COE genes have multiple functions in insects, including neurogenesis, developmental regulation, xenobiotic metabolism, and insecticide detoxification [45]. B. tabaci is a globally invasive pest with a wide host adaptability range. A large number of chemical pesticides are used worldwide for the control 
of $B$. tabaci, resulting in the resistance of $B$. tabaci to insecticides. A comprehensive understanding of $B$. tabaci COE genes will contribute to studies of the physiology, host adaptability, and insecticide resistance of $B$. tabaci. In this study, 42 putative COEs were identified in the B. tabaci MED genome, and the expression patterns of the COE genes among B. tabaci MED developmental stages were detected from the transcriptome. Expression profile analysis of COEs in B. tabaci adults that were treated with imidacloprid at different concentrations and RNAi studies revealed that two COE genes (BTbe5 and BTjhe2) were involved in B. tabaci MED imidacloprid resistance.

In the current study, we found that the hemipteran insects B. tabaci MED and A. pisum had more beta esterase genes but fewer alpha esterase genes than other insects. The alpha esterase genes belong to the intracellular catalytic class of COEs and participate in insect xenobiotic detoxication $[6,46,47]$. Previous studies have shown that beta esterases have multiple functions, especially in the metabolism of xenobiotics and insecticides $[6,17,48]$. Some genes in the beta esterase subfamily of hemipteran insects may perform functions similar to those of alpha esterase subfamily genes in other insects, resulting in a decrease in the number of alpha esterase subfamily genes in B. tabaci MED. We also found that $B$. tabaci had more $n r l$ genes than other insects. $n r l$ genes are essential for establishing and remodeling central nervous system synapses $[49,50]$. Whether the expansion of the $n r l$ genes in $B$. tabaci MED is related to its developmental characteristics or the evolution of new biological functions for some of these genes needs to be further investigated.

The expression profile of the COEs at different developmental stages of B. tabaci MED showed that adult stages clustered together, while eggs and nymphal stages were clustered together. The $\mathrm{COE}$ genes of insects participate in many processes of growth and development. Eggs and nymphs of whiteflies are in the process of rapid growth and development, while adults have completed their development. Therefore, the expression of COEs in B. tabaci MED was clustered as described above. The ecdysone and JH in insect hemolymph regulate insect growth and development in a complex manner [51]. In numerous insects, JH esterase (JHE) plays critical roles in the metabolism of JH by hydrolysis of methyl ester, which is considered the principal pathway for the degradation of $\mathrm{JH}$, and is involved in insect development, metamorphosis, diapause, and reproduction [52]. We detected high expression of JHEs in the 4th-instar nymphs of whiteflies. A previous study indicated that the JHE-like gene (Px004817) of Plutella xylostella is highly expressed in 4th-instar larvae and participates in the induction of larval-to-pupal metamorphosis [53]. JHE genes likely participate in whitefly development from nymphs to adults. The BTgli and BTnrls genes, which belong to the neurodevelopment clade, were expressed at low levels in the adult stage, and most of these genes were highly expressed in the egg stage. This difference may be related to the developmental characteristics of $B$. tabaci. During development from the egg to the nymph, whiteflies develop a complex nervous system; therefore, high expression levels of genes involved in neural development are required. In contrast, at the adult stage, the nervous system is fully developed, and as a result, the expression levels of genes related to nerve development will be reduced. RNA-seq and qRT-PCR are the two main methods for gene expression analysis. Previous studies showed that the correlation of $\mathrm{ABC}$ transporter expression between RNA-seq and qRT-PCR was approximately 0.684 [44], and 50\% (6/12 genes) [43] of amino acid/auxin permease (AAAP) transporter genes showed high consistency between these two methods. In this study, we found that $58 \%$ (7/12 genes) of COE genes showed highly similar patterns between the two methods, indicating that our RNA-seq results effectively reflect the expression level of the genes.

The induction of gene expression represents adaptive plasticity between energy conservation and survival in rapidly changing environments [54-56]. Our expression profiles of COEs in response to imidacloprid challenge in B. tabaci MED showed that most COEs can be induced by imidacloprid, and the expression levels of six $\mathrm{COE}$ genes were positively correlated with the concentration of imidacloprid applied. COEs are among the most important detoxification enzyme systems that participate in the metabolic detoxification of xenobiotics in insects. COEs, which increased in expression with increasing imidacloprid concentration, are more likely to be involved in the resistance of $B$. tabaci. Alpha esterases and beta esterases are widely recognized as major COE clades involved in the detoxification of 
xenobiotics and lipids [7]. BTbe3, BTbe5, and BTae2 were located in these clades, suggesting that these genes play a potentially important role in metabolizing insecticides in B. tabaci. JHE genes are mainly involved in the regulation of hormone metabolism, growth, and development [52]. Whether B. tabaci JHE genes participate in insecticide resistance requires verification by subsequent RNAi experiments.

Neonicotinoid insecticides are important chemical pesticides that are widely used in the control of agricultural pests worldwide [29-31]. In the past few decades, B. tabaci has developed high levels of resistance to neonicotinoids in the field [27,33-37]. Previous studies have shown that the resistance of B. tabaci against neonicotinoid insecticides is mainly related to detoxification $[7,8,34,38,40,57,58]$. The enhanced activity of cytochrome P450 monooxygenases (P450s) is generally recognized as the major mechanism of resistance to imidacloprid in $B$. tabaci $[34,38,39]$. The overexpression of the P450 genes CYP6CM1 and CYP4C64 has been found to be involved in imidacloprid resistance in field B. tabaci [57]. Silencing the GSTd7 gene increased the mortality of whiteflies exposed to imidacloprid [41], and knockdown of GST14 significantly increased the mortality of thiamethoxam-treated B. tabaci MED [40]. Recently, an ATP-binding cassette transporter, ABCG3, was shown to be involved in the resistance of $B$. tabaci to imidacloprid, and silencing the $A B C G 3$ gene by RNAi increased the lethality of imidacloprid to adults of B. tabaci MED [58]. Previous transcriptome analysis revealed that the expression level of six COE genes of B. tabaci MED corresponded to the amount of imidacloprid to which individuals were exposed. We silenced COE gene expression using oral feeding of dsRNA and found that knockdown of the BTbe5 and BTjhe2 genes significantly increased the lethal effect of imidacloprid, indicating that these two genes are involved in the resistance of B. tabaci MED to imidacloprid. In insects, the beta esterase clade genes are recognized as important detoxification enzymes involved in resistance to organophosphorus insecticides $[17,59,60]$. In this study, we found that $B T b e 5$ was involved in the imidacloprid resistance of $B$. tabaci MED. The main function of JHE genes is to regulate the growth and development of insects. $B$. tabaci adults have completed their growth and development. The expression of the JHE genes in the adult stage indicates that these genes may have other biological functions. In this study, we found that a JHE gene participated in the resistance of adult B. tabaci to imidacloprid.

In summary, all COE family genes were identified in B. tabaci MED, and the expression profiles of COEs at different developmental stages of $B$. tabaci were analyzed. Moreover, two COE genes, BTbe 5 and BTjhe2, were found to facilitate B. tabaci MED resistance to imidacloprid. The present results will contribute to functional research on COEs, enrich our understanding of the resistance mechanism of $B$. tabaci MED to imidacloprid, and aid in the development of a management strategy for B. tabaci.

\section{Materials and Methods}

\subsection{Insect Strain}

The colony of B. tabaci MED was collected on poinsettia (Euphorbia pulcherrima Wild. ex K1.) in 2009 in Beijing. It was transferred and continuously maintained on cotton (Gossypium herbaceum L. cv. E-Mian 24) without exposure to chemical pesticides in a glasshouse at $27 \pm 1{ }^{\circ} \mathrm{C}$, with a relative humidity (RH) of $70 \% \pm 10 \%$ and L16:D8 photoperiod. The purity of the colony was monitored by sequencing a fragment of the mitochondrial cytochrome oxidase I (mtCOI) gene every three to five generations [26].

\subsection{De Novo Identification of COE Genes}

To identify the putative COEs in B. tabaci MED, the predicted proteins containing the conserved functional domain of COE defined by the Pfam hidden Markov model (HMM) profile COesterase (PF00135) were identified in the B. tabaci MED genome-predicted protein data set [43] using HMMER (v.3.01) [61]. The COE amino acid sequences of $A$. mellifera and D. melanogaster downloaded from the NCBI (https://www.ncbi.nlm.nih.gov/genome/?term=Apis+mellifera (accessed on 12 March 2018)) and FlyBase (http://flybase.org/ (accessed on 12 March 2018)) were used as queries to search against the $B$. tabaci MED genome to ensure that all the COEs had been identified. A total of 42 putative B. tabaci 
COE genes were confirmed by blasting against the NR database with the BLASTX program on the NCBI website (http://blast.ncbi.nlm.nih.gov/ (accessed on 16 March 2018)). Then, the putative COEs were manually corrected by comparison with assembled expressed sequence tags (ESTs) [44].

\subsection{Phylogenetic Analysis of B. tabaci MED COE Genes}

To comprehensively annotate and systematically classify the COE genes of B. tabaci MED, a phylogenetic tree was constructed based on the putative COE genes of B. tabaci MED and COE amino acid sequences from $D$. melanogaster and A. mellifera. All the selected COE amino acid sequences were aligned using MUSCLE, a module of MEGA 6 (http://www.megasoftware.net/ (accessed on 6 May 2018)) [62]. A phylogenetic tree was generated using the neighbor-joining (NJ) method based on the Jones-Taylor-Thornton (JTT) model with a uniform substitution rate combined with pairwise deletion and 1000 bootstrap replicates.

\subsection{RNA-Seq Analysis}

RNA-seq libraries for different developmental stages of B. tabaci MED and imidacloprid-treated adult B. tabaci MED were obtained from our previous report [44]. Trimmomatic was used to filter the transcriptome datasets [63], and the clean data were mapped to the B. tabaci MED genome with TopHat software $[43,64]$. The fragments per kilobase of transcript per million fragments mapped (FPKM) value was calculated using Cufflinks to estimate the expression level of each predicted transcript [65].

\subsection{RNA Isolation and cDNA Synthesis}

Samples were collected from B. tabaci MED at different developmental stages (eggs, first- to fourth-instar nymphs, and newly emerged (0- to 2-day-old) adults). Total RNA was extracted from each sample using TRIzol reagent (Invitrogen, Carlsbad, CA, USA) following the manufacturer's instructions. RNA quality was evaluated by agarose gel electrophoresis, and the total RNA was quantified using a spectrophotometer (NanoDrop 2000c, Thermo Fisher Scientific Inc., Waltham, MA, USA). The RNA was reverse-transcribed to cDNA with a PrimeScript RT kit (Perfect Real Time) (TaKaRa, Dalian, China) for qRT-PCR analysis and a PrimeScript ${ }^{\mathrm{TM}}$ II 1st strand cDNA synthesis kit (TaKaRa, Dalian, China) for COE double-strand RNA (dsRNA) synthesis. The cDNA was stored at $-80^{\circ} \mathrm{C}$ for later use.

\subsection{Quantitative Real-Time Polymerase Chain Reaction (qRT-PCR) Analysis}

The specific primers for COEs of B. tabaci MED were designed using Primer Premier 5.0 and used to verify the expression levels of COEs by qRT-PCR (Table S2). qRT-PCR was performed using an ABI 7500 system (Applied Biosystems) with the $25-\mu \mathrm{L}$ reaction containing $0.5 \mu \mathrm{L}$ of each specific primer, $0.5 \mu \mathrm{L}$ of $50 \times$ ROX reference dye (TIANGEN, Beijing, China), $1 \mu \mathrm{L}$ of cDNA template, $10 \mu \mathrm{L}$ of $\mathrm{ddH}_{2} \mathrm{O}$, and $12.5 \mu \mathrm{L}$ of $2 \times$ SuperReal PreMix Plus (SYBR Green) (TIANGEN, Beijing, China). The qRT-PCR programme was as follows: $95^{\circ} \mathrm{C}$ for $10 \mathrm{~min}$ (initial denaturation), followed by 40 cycles of $95^{\circ} \mathrm{C}$ for $5 \mathrm{~s}$ (denaturation), $60^{\circ} \mathrm{C}$ for $15 \mathrm{~s}$ (annealing), and $72{ }^{\circ} \mathrm{C}$ for $35 \mathrm{~s}$ (elongation). Only the qRT-PCR primers with $90-110 \%$ amplification efficiencies were used for the subsequent data analysis.

Relative expression levels were quantified using the $2^{-\Delta \Delta C t}$ method [66]. The geometric mean of the reference genes 60S ribosomal protein L29 (RPL29) (GenBank accession no. EE596314) and elongation factor 1 alpha (EF1- $\alpha$ ) (GenBank accession no. EE600682) was used to normalize the expression of target genes $[67,68]$. Three biological replicates and four technical replicates were performed for each sample. One-way analysis of variance (ANOVA) (SPSS 23) was used to detect significant differences between samples.

\section{7. dsRNA Synthesis and RNAi Assays}

BTbe5, BTbe3, BTTjhe1, BTjhe2, BTae2, and BTun2 were selected for RNAi because their expression was positively correlated with the imidacloprid-induced concentration. The dsRNA primers of $B T b e 5$, BTbe3, BTjhe1, BTjhe2, BTae2, BTun2, and EGFP (GenBank: KC896843) with the T7 promoter sequence 
were designed using Primer Premier 5.0 to clone partial cDNA of those genes (Table S2). The dsRNA of BTbe5, BTbe3, BTjhe1, BTjhe2, BTae2, BTun2, and EGFP were synthesized using the T7 Ribomax ${ }^{\mathrm{TM}}$ Express RNAi System (Promega, Madison, WI, USA). The quality of dsRNA was evaluated by gel electrophoresis, and the dsRNA was quantified using a NanoDrop spectrophotometer.

Knockdown of BTbe5, BTbe3, BTjhe1, BTjhe2, BTae2, and BTun2 genes was performed by orally feeding dsRNA to $B$. tabaci MED adults in feeding chambers. The feeding chambers contained $0.2 \mathrm{~mL}$ of diet solution, which contained $30 \%$ sucrose, $5 \%$ yeast extract (weight/volume), with $0.5 \mu \mathrm{g} / \mu \mathrm{L}$ dsBTbe 5 , dsBTbe3, dsBTjhe1, dsBTjhe2, dsBTae2, and dsBTun2 [69]. Approximately 60 newly emerged ( $<2$ days old) B. tabaci MED adults (mixed sexes) were released into the feeding chambers, and were kept at $25^{\circ} \mathrm{C}, 80 \% \mathrm{RH}$, and an L14:D10 photoperiod. The effectiveness of RNAi was determined by qRT-PCR using cDNA synthesized from isolated total adult RNA after 2 days of feeding. Each RNAi treatment was repeated three times.

Bioassays were performed using feeding chambers for $24 \mathrm{~h}$. The living whitefly adults fed dsRNA for $48 \mathrm{~h}$ were transferred to a new feeding chamber containing $50 \mathrm{mg} / \mathrm{L}$ imidacloprid in a diet solution. Bioassays were performed with approximately 40 living whitefly adults per treatment, and each bioassay was replicated three times. Significant differences in the bioassays were determined using SPSS 23 with one-way ANOVA and Holm-Sidak test (overall significance level $=0.05$ ).

Supplementary Materials: Supplementary materials can be found at http://www.mdpi.com/1422-0067/20/20/ 4973/s1. Table S1 Identification of COE genes in the B. tabaci MED genome. Table S2. Primers used to study COEs. Table S3. FPKM values of the COE genes affected by developmental stages of $B$. tabaci MED. Table S4. FPKM values from transcriptome data of COE genes in B. tabaci MED adults treated with an imidacloprid gradient.

Author Contributions: Conceptualization: Y.Z. and J.X.; methodology: J.X. and Y.Z.; software: Z.Y., Z.G., and F.Y.; validation: J.X., H.X., and X.S.; investigation: J.X., H.X., and L.G.; data curation: H.X, X.Y., and W.X.; writing_original draft preparation: J.X. and H.P.; writing—review and editing: J.X., S.W., Q.W., and Y.Z.; funding acquisition: Y.Z.

Funding: This research was supported by the National Natural Science Foundation of China (31420103919 and 31801747), the Beijing Key Laboratory for Pest Control and Sustainable Cultivation of Vegetables, and the Science and Technology Innovation Program of the Chinese Academy of Agricultural Sciences (CAAS-ASTIP-IVFCAAS).

Conflicts of Interest: The authors declare no conflicts of interest.

$\begin{array}{ll}\text { Abbreviations } \\ \text { COE } & \text { Carboxylesterase } \\ \text { RNAi } & \text { RNA interference } \\ \text { FPKM } & \text { Fragments per kilobase of transcript per million fragments mapped } \\ \text { NJ } & \text { Neighbor-joining } \\ \text { JTT } & \text { Jones-Taylor-Thornton } \\ \text { dsRNA } & \text { Double-strand RNA } \\ \text { EGFP } & \text { Enhanced green fluorescent protein } \\ \text { JH } & \text { Juvenile hormone } \\ \text { JHE } & \text { Juvenile hormone esterase } \\ \text { qRT-PCR } & \text { Quantitative real-time polymerase chain reaction } \\ \text { AAAP } & \text { Amino acid/auxin permease } \\ \text { P450 } & \text { Cytochrome P450 monooxygenase } \\ \text { GST } & \text { Glutathione S-transferase } \\ \text { ABC } & \text { ATP-binding cassette transporter } \\ \text { mtCOI } & \text { Mitochondrial cytochrome oxidase I } \\ \text { HMM } & \text { Hidden Markov model } \\ \text { NCBI } & \text { National Center for Biotechnology Information } \\ \text { EST } & \text { Expressed sequence tag }\end{array}$




\section{References}

1. Wheelock, C.E.; Shan, G.; Ottea, J. Overview of carboxylesterases and their role in the metabolism of insecticides. J. Pestic Sci. 2005, 30, 75-83. [CrossRef]

2. Satoh, T.; Hosokawa, M. The mammalian carboxylesterases: From molecules to functions. Annu. Rev. Pharm. Toxicol. 1998, 38, 257-288. [CrossRef] [PubMed]

3. Montella, I.R.; Schama, R.; Valle, D. The classification of esterases: An important gene family involved in insecticide resistance-a review. Mem. Inst. Oswaldo Cruz. 2012, 107, 437-449. [CrossRef] [PubMed]

4. Marshall, S.D.G.; Putterill, J.J.; Plummer, K.M.; Newcomb, R.D. The carboxylesterase gene family from Arabidopsis thaliana. J. Mol. Evol. 2003, 57, 487-500.

5. Bornscheuer, U.T. Microbial carboxylesterases: Classification, properties and application in biocatalysis. Fems. Microbiol. Rev. 2002, 26, 73-81. [CrossRef] [PubMed]

6. Oakeshott, J.G.; Claudianos, C.; Campbell, P.M.; Newcomb, R.D.; Russell, R.J. Biochemical genetics and genomics of insect esterases. In Insect Pharmacology: Channels, Receptors, Toxins and Enzymes, 1st ed.; Elsevier: London, UK, 2005; pp. 309-381.

7. Feng, X.; Li, M.; Liu, N. Carboxylesterase genes in pyrethroid resistant house flies, Musca Domest. Insect Biochem. Molec. Biol. 2018, 92, 30-39. [CrossRef] [PubMed]

8. Alon, M.; Alon, F.; Nauen, R.; Morin, S. Organophosphates' resistance in the B-biotype of Bemisia tabaci (Hemiptera: Aleyrodidae) is associated with a point mutation in an ace1-type acetylcholinesterase and overexpression of carboxylesterase. Insect Biochem. Molec. Biol. 2008, 38, 940-949. [CrossRef]

9. Andrews, M.C.; Callaghan, A.; Field, L.M.; Williamson, M.S.; Moores, G.D. Identification of mutations conferring insecticide-insensitive AChE in the cotton-melon aphid, Aphis gossypii Glover. Insect Mol. Biol. 2004, 13, 555-561. [CrossRef] [PubMed]

10. Li, X.; Schuler, M.A.; Berenbaum, M.R. Molecular mechanisms of metabolic resistance to synthetic and natural xenobiotics. Annu. Rev. Entomol. 2007, 52, 231-253. [CrossRef]

11. Zhu, Y.C.; Dowdy, A.K.; Baker, J.E. Detection of single-base substitution in an esterase gene and its linkage to malathion resistance in the parasitoid Anisopteromalus calandrae (Hymenoptera: Pteromalidae). Pestic. Sci. 1999, 55, 398-404. [CrossRef]

12. Campbell, P.M.; Newcomb, R.D.; Russell, R.J.; Oakeshott, J.G. Two different amino acid substitutions in the ali-esterase, E3, confer alternative types of organophosphorus insecticide resistance in the sheep blowfly, Lucilia cuprina. Insect Biochem. Molec. Biol. 1998, 28, 139-150. [CrossRef]

13. Claudianos, C.; Russell, R.J.; Oakeshott, J.G. The same amino acid substitution in orthologous esterases confers organophosphate resistance on the house fly and a blowfly. Insect Biochem. Molec. Biol. 1999, 29, 675-686. [CrossRef]

14. Small, G.J.; Hemingway, J. Molecular characterization of the amplified carboxylesterase gene associated with organophosphorus insecticide resistance in the brown planthopper, Nilaparvata lugens. Insect Mol. Biol. 2000, 9, 647-653. [CrossRef] [PubMed]

15. Cao, C.W.; Zhang, J.; Gao, X.W.; Liang, P.; Guo, H.L. Overexpression of carboxylesterase gene associated with organophosphorous insecticide resistance in cotton aphids, Aphis gossypii (Glover). Pestic Biochem. Physiol. 2008, 90, 175-180. [CrossRef]

16. Wu, S.; Yang, Y.; Yuan, G.; Campbell, P.M.; Teese, M.G.; Russell, R.J.; Oakeshott, J.G.; Wu, Y. Overexpressed esterases in a fenvalerate resistant strain of the cotton bollworm, Helicoverpa armigera. Insect Biochem. Molec. Biol. 2011, 41, 14-21. [CrossRef]

17. Hawkes, N.J.; Hemingway, J. Analysis of the promoters for the $\beta$-esterase genes associated with insecticide resistance in the mosquito Culex quinquefasciatus. Biochim. Biophys. Acta 2002, 1574, 51-62. [CrossRef]

18. Gong, Y.; Shi, X.; Desneux, N.; Gao, X. Effects of spirotetramat treatments on fecundity and carboxylesterase expression of Aphis gossypii Glover. Ecotoxicology 2016, 25, 655-663. [CrossRef] [PubMed]

19. Lü, F.G.; Fu, K.Y.; Li, Q.; Guo, W.C.; Ahmat, T.; Li, G.Q. Identification of carboxylesterase genes and their expression profiles in the Colorado potato beetle Leptinotarsa decemlineata treated with fipronil and cyhalothrin. Pestic Biochem. Physiol. 2015, 122, 86-95. [CrossRef]

20. Poupardin, R.; Reynaud, S.; Strode, C.; Ranson, H.; Vontas, J.; David, J.P. Crossinduction of detoxification genes by environmental xenobiotics and insecticides in the mosquito Aedes aegypti: Impact on larval tolerance to chemical insecticides. Insect Biochem. Molec. Biol. 2008, 38, 540-551. [CrossRef] 
21. Wei, P.; Shi, L.; Shen, G.; Xu, Z.; Liu, J.; Pan, Y.; He, L. Characteristics of carboxylesterase genes and their expression-level between acaricide-susceptible and resistant Tetranychus cinnabarinus (Boisduval). Pestic Biochem. Physiol. 2016, 131, 87-95. [CrossRef]

22. Reitz, S.R. Invasion of the whiteflies. Science 2007, 318, 1733-1734. [CrossRef]

23. Gelman, D.B.; Blackburn, M.B.; Hu, J.S. Identification of the molting hormone of the sweet potato (Bemisia tabaci) and greenhouse (Trialeurodes vaporariorum) whitefly. J. Insect Physiol. 2005, 51, 47-53. [CrossRef] [PubMed]

24. De Barro, P.J.; Liu, S.S.; Boykin, L.M.; Dinsdale, A.B. Bemisia tabaci: A statement of species status. Annu. Rev. Entomol. 2011, 56, 1-19. [CrossRef] [PubMed]

25. Dinsdale, A.; Cook, L.; Riginos, C.; Buckley, Y.M.; De Barro, P. Refined global analysis of Bemisia tabaci (Hemiptera: Sternorrhyncha: Aleyrodoidea: Aleyrodidae) mitochondrial cytochrome oxidase I to identify species level genetic boundaries. Ann. Entomol. Soc. Am. 2010, 103, 196-208. [CrossRef]

26. Chu, D.; Wan, F.H.; Zhang, Y.J.; Brown, J.K. Change in the biotype composition of Bemisia tabaci in Shandong province of China from 2005 to 2008. Env. Entomol. 2010, 39, 1028-1036. [CrossRef] [PubMed]

27. Pan, H.; Preisser, E.L.; Chu, D.; Wang, S.; Wu, Q.; Carrière, Y.; Zhou, X.; Zhang, Y. Insecticides promote viral outbreaks by altering herbivore competition. Ecol. Appl. 2015, 25, 1585-1595. [CrossRef] [PubMed]

28. Zheng, H.; Xie, W.; Wang, S.; Wu, Q.; Zhou, X.; Zhang, Y. Dynamic monitoring (B versus Q) and further resistance status of Q-type Bemisia tabaci in China. Crop Prot. 2017, 94, 115-122. [CrossRef]

29. Jeschke, P.; Nauen, R.; Schindler, M.; Elbert, A. Overview of the status and global strategy for neonicotinoids. J. Agric. Food Chem. 2011, 59, 2897-2908. [CrossRef]

30. Nauen, R.; Jeschke, P.; Copping, L. In focus: Neonicotinoid insecticides editorial. Pest Manag. Sci. 2008, 64, 1081. [CrossRef] [PubMed]

31. Bass, C.; Denholm, I.; Williamson, M.S.; Nauen, R. The global status of insect resistance to neonicotinoid insecticides. Pestic. Biochem. Physiol. 2015, 121, 78-87. [CrossRef]

32. Cahill, M.; Gorman, K.; Day, S.; Denholm, I.; Elbert, A.; Nauen, R. Baseline determination and detection of resistance to imidacloprid in Bemisia tabaci (Homoptera: Aleyrodidae). Bull. Entomol. Res. 1996, 86, 343-349. [CrossRef]

33. Palumbo, J.C.; Horowitz, A.R.; Prabhaker, N. Insecticidal control and resistance management for Bemisia tabaci. Crop Prot. 2001, 20, 739-765. [CrossRef]

34. Roditakis, E.; Morou, E.; Tsagkarakou, A.; Riga, M.; Nauen, R.; Paine, M.; Morin, S.; Vontas, J. Assessment of the Bemisia tabaci CYP6CM1vQ transcript and protein levels in laboratory and field-derived imidacloprid-resistant insects and cross-metabolism potential of the recombinant enzyme. Insect Sci. 2011, 18, 23-29. [CrossRef]

35. Byrne, F.J.; Castle, S.; Prabhaker, N.; Toscano, N.C. Biochemical study of resistance to imidacloprid in biotype B Bemisia tabaci from Guatemala. Pest Manag. Sci. 2003, 59, 347-352. [CrossRef] [PubMed]

36. Wang, Z.; Yan, H.; Yang, Y.; Wu, Y. Biotype and insecticide resistance status of the whitefly Bemisia tabaci from China. Pest Manag. Sci. 2010, 66, 1360-1366. [CrossRef]

37. Kontsedalov, S.; Abu-moch, F.; Lebedev, G.; Czosnek, H.; Horowitz, A.R.; Ghanim, M. Bemisia tabaci biotype dynamics and resistance to insecticides in Israel during the years 2008-2010. J. Integr. Agric. 2012, 11, 312-320. [CrossRef]

38. Karunker, I.; Benting, J.; Lueke, B.; Ponge, T.; Nauen, R.; Roditakis, E.; Vontas, J.; Gorman, K.; Denholm, I.; Morin, S. Over-expression of cytochrome P450 CYP6CM1 is associated with high resistance to imidacloprid in the B and Q biotypes of Bemisia tabaci (Hemiptera: Aleyrodidae). Insect Biochem. Molec. Biol. 2008, 38, 634-644. [CrossRef]

39. Karunker, I.; Morou, E.; Nikou, D.; Nauen, R.; Sertchook, R.; Stevenson, B.J.; Paine, M.J.I.; Morin, S.; Vontas, J. Structural model and functional characterization of the Bemisia tabaci CYP6CM1vQ, a cytochrome P450 associated with high levels of imidacloprid resistance. Insect Biochem. Molec. Biol. 2009, 39, 697-706. [CrossRef]

40. Yang, X.; He, C.; Xie, W.; Liu, Y.; Xia, J.; Yang, Z.; Guo, L.; Wen, Y.; Wang, S.; Wu, Q.; et al. Glutathione S-transferases are involved in thiamethoxam resistance in the field whitefly Bemisia tabaci Q (Hemiptera: Aleyrodidae). Pestic. Biochem. Physiol. 2016, 134, 73-78. [CrossRef] 
41. He, C.; Xie, W.; Yang, X.; Wang, S.L.; Wu, Q.J.; Zhang, Y.J. Identification of glutathione S-transferases in Bemisia tabaci (Hemiptera: Aleyrodidae) and evidence that GSTd7 helps explain the difference in insecticide susceptibility between B. tabaci Middle East-Minor Asia 1 and Mediterranean. Insect Mol. Biol. 2018, 27, 22-35. [CrossRef]

42. Hamada, A.; Wahl, G.D.; Nesterov, A.; Nakao, T.; Kawashima, M.; Banba, S. Differential metabolism of imidacloprid and dinotefuran by Bemisia tabaci CYP6CM1 variants. Pestic. Biochem. Physiol. 2019, 159, 27-33. [CrossRef] [PubMed]

43. Xie, W.; Chen, C.; Yang, Z.; Guo, L.; Yang, X.; Wang, D.; Chen, M.; Huang, J.; Wen, Y.; Zeng, Y.; et al. Genome sequencing of the sweetpotato whitefly Bemisia tabaci MED/Q. GigaScience 2017, 6, 1-7. [CrossRef] [PubMed]

44. Tian, L.; Song, T.; He, R.; Zeng, Y.; Xie, W.; Wu, Q.; Wang, S.; Zhou, X.; Zhang, Y. Genome-wide analysis of ATP-binding cassette $(\mathrm{ABC})$ transporters in the sweetpotato whitefly, Bemisia tabaci. BMC Genom. 2017, 18, 330. [CrossRef] [PubMed]

45. Yu, Q.Y.; Lu, C.; Li, W.L.; Xiang, Z.H.; Zhang, Z. Annotation and expression of carboxylesterases in the silkworm, Bombyx mori. BMC Genom. 2009, 10, 553. [CrossRef] [PubMed]

46. Claudianos, C.; Ranson, H.; Johnson, R.M.; Biswas, S.; Schuler, M.A.; Berenbaum, M.R.; Feyereisen, R.; Oakeshott, J.G. A deficit of detoxification enzymes: Pesticide sensitivity and environmental response in the honeybee. Insect Mol. Biol. 2006, 15, 615-636. [CrossRef]

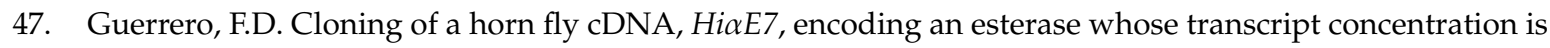
elevated in diazinon-resistant flies. Insect Biochem. Molec. Biol. 2000, 30, 1107-1115. [CrossRef]

48. Robin, C.; Bardsley, L.M.J.; Coppin, C.; Oakeshott, J.G. Birth and death of genes and functions in the $\beta$-esterase cluster of Drosophila. J. Mol. Evol. 2009, 69, 10-21. [CrossRef]

49. Scheiffele, P.; Fan, J.; Choih, J.; Fetter, R.; Serafini, T. Neuroligin expressed in nonneuronal cells triggers presynaptic development in contacting axons. Cell 2000, 101, 657-669. [CrossRef]

50. Chen, X.; Liu, H.; Shim, A.H.R.; Focia, P.J.; He, X. Structural basis for synaptic adhesion mediated by neuroligin-neurexin interactions. Nat. Struct. Mol. Biol. 2008, 15, 50-56. [CrossRef]

51. Tan, A.; Tanaka, H.; Tamura, T.; Shiotsuki, T. Precocious metamorphosis in transgenic silkworms overexpressing juvenile hormone esterase. Proc. Natl. Acad. Sci. USA 2005, 102, 11751-11756. [CrossRef]

52. Riddiford, L.M.; Hiruma, K.; Zhou, X.; Nelson, C.A. Insights into the molecular basis of the hormonal control of molting and metamorphosis from Manduca sexta and Drosophila melanogaster. Insect Biochem. Molec. Biol. 2003, 33, 1327-1338. [CrossRef]

53. Gu, X.; Kumar, S.; Kim, E.; Kim, Y. A whole genome screening and RNA interference identify a juvenile hormone esterase-like gene of the diamondback moth, Plutella Xylostella. J. Insect Physiol. 2015, 80, 81-87. [CrossRef] [PubMed]

54. Zhu, F.; Li, T.; Zhang, L.; Liu, N. Co-up-regulation of three P450 genes in response to permethrin exposure in permethrin resistant house flies, Musca domestica. Bmc. Physiol. 2008, 8, 18. [CrossRef] [PubMed]

55. Terriere, L.C. Induction of detoxication enzymes in insects. Ann. Rev. Entomol. 1984, 29, 71-88. [CrossRef] [PubMed]

56. Tao, X.Y.; Xue, X.Y.; Huang, Y.P.; Chen, X.Y.; Mao, Y.B. Gossypol-enhanced P450 gene pool contributes to cotton bollworm tolerance to a pyrethroid insecticide. Mol. Ecol. 2012, 21, 4371-4385. [CrossRef] [PubMed]

57. Yang, X.; Xie, W.; Wang, S.; Wu, Q.; Pan, H.; Li, R.; Yang, N.; Liu, B.; Xu, B.; Zhou, X.; et al. Two cytochrome P450 genes are involved in imidacloprid resistance in field populations of the whitefly, Bemisia tabaci, in China. Pestic. Biochem. Physiol. 2013, 107, 343-350. [CrossRef] [PubMed]

58. He, C.; Liang, J.; Liu, S.; Wang, S.; Wu, Q.; Xie, W.; Zhang, Y. Changes in the expression of four ABC transporter genes in response to imidacloprid in Bemisia tabaci Q (Hemiptera: Aleyrodidae). Pestic. Biochem. Physiol. 2019, 153, 136-143. [CrossRef] [PubMed]

59. Hemingway, J.; Hawkes, N.J.; McCarroll, L.; Ranson, H. The molecular basis of insecticide resistance in mosquitoes. Insect Biochem. Molec. Biol. 2004, 34, 653-665. [CrossRef] [PubMed]

60. Ocampo, C.B.; Salazar-Terreros, M.J.; Mina, N.J.; McAllister, J.; Brogdon, W. Insecticide resistance status of Aedes aegypti in 10 localities in Colombia. Acta. Trop. 2011, 118, 37-44. [CrossRef]

61. Eddy, S.R. Profile hidden Markov models. Bioinformatics 1998, 14, 755-763. [CrossRef]

62. Tamura, K.; Stecher, G.; Peterson, D.; Filipski, A.; Kumar, S. Mega 6: Molecular evolutionary genetics analysis version 6.0. Mol. Biol. Evol. 2013, 30, 2725-2729. [CrossRef] [PubMed] 
63. Bolger, A.M.; Lohse, M.; Usadel, B. Trimmomatic: A flexible trimmer for Illumina sequence data. Bioinformatics 2014, 30, 2114-2120. [CrossRef] [PubMed]

64. Trapnell, C.; Pachter, L.; Salzberg, S.L. Tophat: Discovering splice junctions with RNA-Seq. Bioinformatics 2009, 25, 1105-1111. [CrossRef] [PubMed]

65. Trapnell, C.; Williams, B.A.; Pertea, G.; Mortazavi, A.; Kwan, G.; van Baren, M.J.; Salzberg, S.L.; Wold, B.J.; Pachter, L. Transcript assembly and quantification by RNA-Seq reveals unannotated transcripts and isoform switching during cell differentiation. Nat. Biotechnol. 2010, 28, 511-515. [CrossRef] [PubMed]

66. Livak, K.J.; Schmittgen, T.D. Analysis of relative gene expression data using real-time quantitative PCR and the $2^{-\Delta \Delta C T}$ method. Methods 2001, 25, 402-408. [CrossRef] [PubMed]

67. Vandesompele, J.; De Preter, K.; Pattyn, F.; Poppe, B.; Van Roy, N.; De Paepe, A.; Speleman, F. Accurate normalization of real-time quantitative RT-PCR data by geometric averaging of multiple internal control genes. Genome Biol. 2002, 3, 0034. [CrossRef] [PubMed]

68. Li, R.; Xie, W.; Wang, S.; Wu, Q.; Yang, N.; Yang, X.; Pan, H.; Zhou, X.; Bai, L.; Xu, B.; et al. Reference gene selection for qRT-PCR analysis in the sweetpotato whitefly, Bemisia tabaci (Hemiptera: Aleyrodidae). PLoS ONE 2013, 8, e53006. [CrossRef]

69. Xia, J.; Yang, Z.; Gong, C.; Xie, W.; Pan, H.; Guo, Z.; Zheng, H.; Yang, X.; Sun, X.; Kang, S.; et al. Genome-wide identification and expression analysis of amino acid transporters in the whitefly, Bemisia tabaci (Gennadius). Int. J. Biol. Sci. 2017, 13, 735-747. [CrossRef]

(C) 2019 by the authors. Licensee MDPI, Basel, Switzerland. This article is an open access article distributed under the terms and conditions of the Creative Commons Attribution (CC BY) license (http://creativecommons.org/licenses/by/4.0/). 